\title{
Dukungan Sosial dan Religiusitas Terhadap Kecemasan Yang Tinggal Sendiri Selama Masa Pandemi Covid-19
}

\author{
Kasmayani Karim, Nono Hery Yoenanto \\ Fakultas Psikologi Universitas Airlangga \\ email: kasmayani.karim-2019@psikologi.unair.ac.id
}

\section{Artikel INFO \\ Diterima:19 Oktober 2020 Direvisi :20 April 2021 \\ Disetujui:30 Agustus 2021 \\ DOI: \\ http://dx.doi.org/10.24014/ jp.v14i2.11034}

\section{Abstrak}

\begin{abstract}
Masyarakat merasakan kecemasan selama masa pandemi Covid-19, khususnya seseorang yang tinggal sendiri. Kecemasan yang dirasakan mungkin saja disebabkan oleh dukungan sosial dan tingkat religiusitas yang dimiliki. Penelitian ini bertujuan menguji pengaruh dukungan sosial dan religiusitas terhadap kecemasan masyarakat yang tinggal sendiri selama masa pandemi Covid-19. Penelitian ini menggunakan metode kuantitatif dan pengambilan data $(n=151)$ dengan teknik purposive sampling. Partisipan diperoleh melalui kuesioner online yang disebarkan dan sesuai dengan kriteria yang telah ditetapkan oleh peneliti. Kriteria partisipan yaitu berusia minimal 18 tahun dan tinggal sendiri selama masa pandemi Covid 19. Pengumpulan data dilakukan melalui koesioner yang didistribusikan secara online dalam bentuk google form dan disebarkan melalui beberapa media sosial, yaitu instagram, whatshapp dan facebook. Teknik pengumpulan data yang digunakan adalah adalah skala likert. Ada 3 skala yang digunakan yaitu skala dukungan sosial, skala religiusitas dan skala kecamasan. Analisis data yang digunakan yaitu multiple regression. Hasil uji multiple regression menunjukkan bahwa dukungan sosial dan religiusitas signifikan berpengaruh terhadap kecemasan masyarakat yang tinggal sendiri selama masa pandemi Covid-19. Dukungan sosial dan religiusitas dapat mengatasi kecemasan dalam menghadapi pandemi Covid-19.
\end{abstract}

Kata-kata kunci: Dukungan Sosial; Pandemi Covid -19; Kecemasan; Religiusitas

\section{Social support and religiosity on anxiety who live alone during the covid-19 pandemic}

\begin{abstract}
People feel anxiety during the Covid-19 pandemic, especially someone who lives alone. Anxiety may be caused by social support and the level of religiolity possessed. This research is intended to examine the role of social support and religiosity on the anxiety of people living alone during the Covid-19 pandemic. This research uses quantitative methods and data collected $(n=151)$ with purposive sampling technique. Participants were obtained by an online questionnaire that was distributed and based on criteria by researcher. The partisipants criteria are minimum age of 18 years and living alone during the Covid-19 pandemic. Data collection is done by questionnaires that are distributed online in the form of google forms and are distributed by several social media, Instagram, Whatsapp and Facebook. The data collection technique is the Likert scale. There are three measuring instruments are social support, religiosity scale and anxiety scale. Data analysis used is multiple regression analysis. The multiple regression analysis showed that social support and religiosity significantly influence the anxiety of people living alone during the Covid-19 pandemic. Social support and religiosity can overcome anxiety during the Covid-19 pandemic
\end{abstract}

Keywords: Anxiety; Religiosity; Social support; the Covid-19 pandemic.

\section{Pendahuluan}

Covid-19 (corona virus disease 2019) merupakan wabah yang sedang menimpa dunia. Wabah ini disebabkan oleh infeksi SARS-COV-2 yang dideteksi di Wuhan, Provinsi Hubei, China pada bulan desember 2019 (Huang, Zhao, Li, Chen, Zhao, Deng
\& Song, 2020). Organisasi kesehatan dunia (WHO) telah menetapkan wabah tersebut sebagai pandemi dunia (Djalante, Lassa, Setiamarga, Sudjatma, Indrawan, Haryanto, Mahfud, Sinapoy, Djalante, Rafliana, Gunawan, Surtiari \& Warsilah, 2020). Covid-19 merupakan sebuah penyakit baru yang berbeda dari SARS, MERS dan 
influenza lainnya (WHOa, 2020).

Covid-19 merupakan penyakit menular yang berjangkit dengan cepat dengan masa penularan 5-6 hari bahkan sampai 14 hari sebelum individu menjadi bergejala (Tosepu, Gunawan, Effendy, Ahmad, Lestari, Bahar \& Asfian, 2020). Penularan virus dapat terjadi dari orang ke orang melalui kontak tangan di mana permukaan telah terkontaminasi dengan virus kemudian menyentuh daerah wajah seperti mulut hidung atau mata. Selain itu, seseorang akan tertular melalui percikan batuk, bersin atau pendarahan pada perkemukaan dengan jarak $2 \mathrm{~m}$ dari orang yang terinfeksi (Thomas, Baldwin, Bissett, Boden, Gosselink, Granger, Hodgson, Jones, Kho, Moses, Ntoumenopoulos, Parry, Patman \& Lee, 2020). Penyakit ini rentan tertular pada orang yang telah tua dan memiliki masalah kesehatan (Adler dalam Shim, Tariq, Choi, Lee \& Chowell, 2020). Kemudian, seseorang yang terinfeksi Covid-19 dapat mengalami pneumia, gagal ginjal, sindrom pernapasan akut dan kematian (Tosepu, Gunawan, Effendy, Ahmad, Lestari, Bahar \& Asfian, 2020).

Virus Covid-19 merupakan sebuah virus yang berbahaya dan mengakibatkan angka kematian yang sangat tinggi. Menurut data worldometers pada 16 April 2020 menunjukkan kasus covid mencapai 2.083.070 di seluruh dunia, dari jumlah tersebut sebanyak 134.607 dinyatakan meninggal dunia (Putsantra, 2020). Sejumlah negera telah terpapar oleh kasus Covid-19, pada 16 April 2020 dilaporkan 200 lebih negara telah terkomfirmasi terpapar Covid-19 (WHOb, 2020). Indonesia merupakan salah satu negara yang terpapar kasus virus Covid-19. Presiden Indonesia mengumumkan 2 kasus Covid-19 pada 2 Maret 2020 (Ihsanuddin, 2020). Kasus tersebut setiap harinya bertambah dan saat ini telah tercatat sebanyak 5136 kasus Covid di Indonesia, dari jumlah tersebut sebanyak 469 dinyatakan meninggal dunia pada 16 April 2020 (Sari, Yahya \& Maharani, 2020).
Pemerintah telah menerapkan berbagai kebijakan untuk memutuskan rantai virus Covid-19 mulai dari memberikan himbauan untuk menerapkan social distancing sampai mengeluarkan peraturan Pembatasan Sosial Berskala Besar (PSBB) yang telah ditetapkan oleh menteri Kesehatan Republik Indonesia (Tamtomo, 2020). Pembatasan Sosial Berskala Besar (PSBB) merupakan suatu pembatasan yang dilakukan terkait kegiatan masyarakat dalam suatu wilayah yang terinfeksi Covid-19 dan untuk mencegah kemungkinan penyebaraan virus yang dapat terjadi. Adapun PSBB di antaranya kegiatan belajar mengajar dan bekerja dilakukan di rumah, pembatasan pada kegiatan sosial dan budaya, transportasi, keagamaan, kegiatan yang dilakukan di tempat umum dan kegiatan lainnya khsusunya aspek pertahanan dan keamanan (Tamtomo, 2020). Kebijakankebijakan tersebut tentu berdampak banyak pada berbagai aspek kehidupan masyarakat. Meskipun demikian, masyarakat diharapkan dapat mematuhi serangkaian kebijakan yang telah dibuat oleh pemerintah untuk mengatasi penyebaran virus Covid-19 dan menimbulkan dampak psikologis bagi masyarakat karena merupakan virus yang berbahaya.

Asosiasi Psikiatri Amerika (APA) di Amerika Serikat telah melakukan survei terhadap orang dewasa sebanyak 1000 orang lebih (Anna, 2020). Berdasarkan survei tersebut diperoleh bahwa sebanyak 48 persen responden mengalami kecemasan terkait penularan virus Covid-19. Selain itu, sekitar 40 persen membuat mereka merasa khawatir terkait dampak yang terjadi yaitu sakit berat bahkan menyebabkan kematian serta 62 persen merasa cemas pada keluarga yang tertular, 36 persen berpendapat bahwa virus Covid-19 berdampak pada kesehatan mental dan 59 persen mengatakan bahwa virus covid-19 memiliki pengaruh yang besar pada kehidupan masyarakat sehari-hari (Anna, 2020). Hal tersebut sesuai dengan hasil penelitian yang dilakukan oleh Roy, Tripathy, 
Kar, Sharma, Verma \& Kaushal (2020) bahwa masyarakat merasa khawatir setelah melihat postingan terkait Covid-19 dan disibukkan dengan pemikiran terkait Covid-19. Hal tersebut juga pasti terjadi pada masyarakat disejumlah negara yang terjangkit virus Covid-19, salah satunya Indonesia.

Beberapa warga Indonesia menyatakan merasa cemas setelah pemerintah memberitahu kepada masyarakat bahwa terdapat dua warga Indonesia yang terinfeksi virus Covid-19 pada awal maret 2020 (Firmansyah, 2020). Penambahan jumlah kasus Covid-19yang setiap hari meningkat dan diikuti dengan jumlah kematian yang banyak, tidak dapat dipungkiri menyebabkan banyak masyarakat merasakan kecemasan. Hal inilah yang mendorong Himpunan Psikologi Indonesia (HIMPSI) dan Ikatan Psikolog Klinis (IPK) membuka dan memberikan layanan psikologi secara daring. Selain itu, menurut ketua Ikatan Psikologi Klinis, beberapa psikolog harus mendatangi pasien untuk memberikan pelayanan (Firmansyah, 2020). Berdasarkan hal tersebut dapat disimpulkan bahwa masyarakat mengalami kecemasan karena pandemi Covid-19.

Kecemasan merupakan kondisi saat seseorang merasakan kegelisahan atau kekhawatiran, perasaan yang tidak nyaman dan tegang terkait kemungkinan suatu hal buruk akan terjadi (Halgin \& Whitboune, 2010). Seseorang yang mengalami kecemasan akan sangat takut, cemas atau menghindari ancaman yang dirasakan seperti situasi sosial atau internal dalam diri sendiri (Craske \& Stein, 2016). Hal inilah yang terjadi pada masyarakat, dimana mareka merasa cemas karena adanya situasi sosial yaitu pandemi Covid-19. Kecemasan mungkin lebih dirasakan oleh mereka yang hidup sendiri sebagai anak kost yang sedang menempuh pendidikan dan sedang bekerja di luar daerah daripada mereka yang tinggal bersama dengan keluarga. Mereka harus mandiri dan harus melakukan semua dengan sendiri.
Sebuah studi penelitian menemukan bahwa seseorang yang tinggal di kos akan memiliki tingkat kecemasan yang tinggi dibandingkan mereka yang tinggal bersama dengan orang tua (Ulfadhina, 2015; Wijayanti, 2016).

Kecemasan yang dirasakan terkait suatu situasi dipengaruhi oleh beberapa faktor. Dari hasil penelitian sebelumnya menunjukkan bahwa kecemasan dipengaruhi oleh usia, pendidikan, pengetahuan, kesehatan fisik dan jiwa, spiritual, tahap perkembangan, respon koping, pengalaman masa lalu dan dukungan sosial yang dimiliki seseorang (Stuart \& Sundeen, 2000). Pada penelitian ini penulis berfokus pada dukungan sosial dan religiusitas dengan pertimbangan kedua faktor tersebut memiliki pengaruh positif terhadap kecemasan seseorang menghadapi situasi pandemi Covid 19 saat ini. Fetriyah, Mahmudah, Damayanti \& Firdaus (2019) menyatakan bahwa dukungan sosial menjadi salah satu faktor utama untuk mengurangi kecemasan. Hal tersebut sesuai pernyataan Han, Yan, Zhang, Zhao, Sun, Li, Lei, Liu \& Chen (2014) mengemukakan bahwa dukungan sosial mempengaruhi gejala kecemasan seseorang.

Seseorang yang memiliki dukungan sosial yang kurang, ia memiliki kecemasan yang berlebihan. Kurniawati (2012) menyatakan semakin tinggi tingkat dukungan sosial seseorang maka semakin rendah tingkat kecemasannya. Dukungan sosial merupakan hal yang sangat penting diperoleh dalam kehidupan. Dukungan sosial adalah sumber daya sosial yang diberikan untuk membantu orang lain (Gottlieb \& Bergen, 2010). Dukungan sosial terkait dengan relasi diri, dukungan yang diperoleh dari orang tertentu maupun orang lain yang menjadi bagian dari orientasi individu dalam hubungan interpersonal (Sarason \& Sarason, 2009). Pemberian dukungan sosial dapat memberikan pengaruh terhadap konsep diri, sikap dan perilaku inividu (Sarason \& Sarason, 2009). 
Selain dukungan sosial, faktor yang mungkin juga mempengaruhi kecemasan pada masyarakat yaitu religiusitas. Religiusitas merupakan perilaku yang berkaitan dengan agama berupa penghayatan pada nilai-nilai agama yang ditandai dengan kepatuhan seseorang dalam menjalankan ibadah, kepercayaan, pengetahuan dan pengalaman yang dimiliki seseorag pada agama yang dianut (Ancok \& Suroso, 2011). Religiusitas berpengaruh terhadap kecemasan seseorang, di mana ketika seseorang memiliki tingkat religiusitas yang tinggi maka akan memiliki tingkat kecemasan yang rendah. Sebaliknya, ketika seseorang memiliki tingkat religiusitas yang rendah maka semakin tinggi tingkat kecemasan yang dimiliki (Wijayanti, 2016; Amrai, Zalani, Arfai \& Sharifian, 2011). Religius dapat menenangkan orang-orang yang merasa takut atau cemas, meningkatkan perasaan aman dan meningkatkan kepercayaan diri atau kepercayaan pada sang ilahi (Koenig, 2009). Penelitian yang akan dilakukan ini bertujuan untuk mengetahui pengaruh dukungan sosial dan religiusitas terhadap kecemasan masyarakat yang tinggal sendiri selama masa pandemi Covid-19. Terkait hal tersebut, hipotesis dari penelitian ini adalah terdapat pengaruh dukungan sosial dan religiusitas terhadap kecemasan masyarakat yang tinggal sendiri selama masa pandemi Covid-19.

\section{Metode}

Penelitian ini merupakan penelitian pendekatan kuantitatif dengan variabel bebas adalah dukungan sosial (X1) dan religiusitas (X2) dengan variabel terikat adalah kecemasan $(Y)$.

\section{Subjek}

Partisipan dalam penelitian ini adalah masyarakat Indonesia yang berusia minimal 18 tahun dan tinggal sendiri selama pandemi. Partisipan berjumlah 151 orang yang dipilih melalui teknik purposive sampling. Partisipan diperoleh melalui kuesioner online yang disebarkan dan memiliki kesesuaian dengan kriteria yang telah ditetapkan oleh peneliti. Berikut gambaran deskriptif demografi partisipan dapat dilihat pada tabel di bawah ini:

Tabel 1. Deskripsi jenis kelamin dan usia partisipan

\begin{tabular}{ccc}
\hline Jenis kelamin & Jumlah Partisipan & Presentase (\%) \\
\hline Perempuan & 90 & $60 \%$ \\
Laki-laki & 61 & $40 \%$ \\
\hline Usia (Tahun) & & \\
\hline $19-23$ & 34 & $22 \%$ \\
$24-28$ & 101 & $67 \%$ \\
$29-33$ & 14 & $9 \%$ \\
$34-38$ & 1 & $1 \%$ \\
$39-43$ & 1 & $1 \%$ \\
\hline
\end{tabular}

Berdasarkan tabel di atas menunjukkan bahwa partisipan perempuan dalam penelitian ini sebanyak 90 orang (60\%) dan partisipan laki-laki sebanyak 61 orang (40\%). Selain itu, partisipan dalam penelitian ini terdiri dari 151 orang dengan rincian 34 orang yang berusia 19 sampai 23 tahun (22\%), 101 orang yang berusia 24 sampai 28 tahun (67\%), 14 orang yang berusia 29 sampai 33 (9\%) dan 1 orang yang berusia 34 sampai 38 (1\%) dan 1 orang yang berusia 39 sampai 43 tahun (1\%).

\section{Pengukuran}

Ada tiga jenis skala yang digunakan pada penelitian ini yaitu skala dukungan sosial, skala religiusitas dan skala kecamasan. Skala yang 
digunakan untuk mengukur dukungan sosial dikembangkan oleh peneliti berdasarkan tiga dimensi yaitu Social Embeddedness, Enacted Support, dan Perceived Support (Barrera, 1986), kemudian telah melalui melalui analisis dari professional judgement. Skala ini terdiri dari 14 aitem dengan pilihan jawaban yang digunakan ada 5 alternatif yakni Sangat Setuju (5), Setuju (4), Netral (3), Tidak Setuju (2) dan Sangat Tidak Setuju (1). Koefisien alfa dari skala ini adalah 0.827 dikatakan reliabel. Pengukuran semakin reliabel ketika angka koefisien reliabilitas semakin mendekati angka 1,00 (Azwar, 2015). Koefisien validitas adalah 0.356 - 0.582 dan dianggap valid sebab mencapai koefisien korelasi minimal 0,30 (Azwar, 2015). Beberapa pertanyaan dalam kuesioner ini yaitu keluarga/teman menanyakan kabar saya, keluarga/teman mengajarkan cara mengatasi Covid-19, keluarga/teman memberikan saran untuk menyediakan ADP (Alat Pelindung Diri), dan lain sebagainya.

Pengukuran religisuitas menggunakan skala yang dikembangkan oleh Stefan Huber \& Odilo Huber (2012). Skala ini dibuat berdasarkan 5 dimensi yaitu intellect, ideology, public practice, private practice dan esperience. Skala ini kemudian dimodifikasi oleh Laili (2018) dan didapatkan hasil reabilitas 0,95. Skala ini terdiri dari 20 aitem dengan pilihan jawaban yang digunakan ada 5 alternatif yakni Sangat Setuju (5), Setuju (4), Netral (3), Tidak Setuju (2) dan Sangat Tidak Setuju (1). Peneliti mengadaptasi skala Laili dan melakukan uji coba dengan memperoleh koefisien alfa sebesar 0,899 dikatakan reliabel. Pengukuran semakin reliabel ketika angka koefisien reliabilitas semakin mendekati angka 1,00 (Azwar, 2015). Koefisien validitas adalah $0.404-0.746$ dan dianggap valid sebab mencapai koefisien korelasi minimal 0,30 (Azwar, 2015). Beberapa pertanyaan dalam kuesioner ini yaitu saya percaya bahwa Tuhan itu ada, saya mengikuti kegiatankegiatan keagamaan, bagi saya taat dalam beribadah adalah hal yang penting, dan lain sebagainya.

Pengukuran kecemasan menggunakan skala yang dikembangkan oleh Hamilton (1959). Skala ini kemudian diadaptasi oleh Ramdan (2018) dan didapatkan hasil $r$ > 0.75 . Skala ini terdiri dari 14 aitem dengan pilihan jawaban semua gejala ada (4), Lebih dari separuh gejala yang ada (3), Separuh gejala yang ada (2), Satu gejala yang ada (1) dan Tidak ada gejala yang ada (0). Peneliti kemudian mengadaptasi skala Ramdan dan melakukan uji coba dengan memperoleh koefisien alfa sebesar 0. 892 dikatakan reliabel. Pengukuran semakin reliabel ketika angka koefisien reliabilitas semakin mendekati angka 1,00 (Azwar, 2015). Koefisien validitas adalah 0.568 - 0.778 dan dianggap valid sebab mencapai koefisien korelasi minimal 0,30 (Azwar, 2015). Beberapa pertanyaan dalam kuesioner ini yaitu memikirkan hal-hal yang menakutkan, merasa khawatir, mudah marah atau mudah tersinggung selama pandemi Covid-19, merasa gelisah, mudah terkejut, kaku pada leher. badan gemetaran, mudah merasa lelah atau meneteskan air mata selama pandemi Covid-19, dan takut akan suasana gelap, takut terhadap orang yang belum dikenal, takut pada hewan, takut ditinggal sendiri atau berada ditengah keramaian selama pandemi Covid-19, dan lain sebagainya.

\section{Analisis Data}

Teknik analisis yang digunakan dalam penelitian ini adalah multiple regression analysis, untuk menganalisi pengaruh dukungan sosial dan religiusitas terhadap kecemasan masyarakat yang tinggal sendiri dalam masa pandemi Covid-19. Data dianalisis dengan menggunakan program SPSS. 
Hasil

Kemudian peneliti melakukan analisis deskriptif bertujuan untuk memberikan gambaran data terkait jumlah data, rentang data (range), nilai minimum, nilai maksimum, nilai rata-rata (mean) dan nilai standar deviasi (SD). Hasil analisi data dengan statistik deskriptif disajikan sebagai berikut:

Tabel 2. Analisis Statistik Deskriptif

\begin{tabular}{ccccccc}
\hline Variabel & $\mathrm{N}$ & Range & Min & Max & Mean & SD \\
\hline Dukungan sosial & 151 & 37 & 33 & 70 & 55.09 & 6.684 \\
Religiusitas & 151 & 55 & 45 & 100 & 85.48 & 10.279 \\
Kecemasan & 151 & 34 & 0 & 34 & 7.70 & 8.909 \\
\hline
\end{tabular}

Berdasarkan tabel di atas menunjukkan bahwa jumlah data $(\mathrm{N})$ yang dianalisis sebanyak 151. Variabel dukungan sosial mempunyai nilai minimum sebesar 33 dan nilai maksimum sebesar 70 dengan nilai ratarata 55.09. Variabel religiusitas mempunyai nilai minimum sebesar 45 dan nilai maksimum sebesar 100 dengan nilai ratarata 85.48 . Variabel kecemasan mempunyai nilai minimum sebesar 0 dan nilai maksimum sebesar 34 dengan nilai rata-rata 7.70. Standar deviasi pada variabel dukungan sosial yaitu 6.684 , religiusitas yaitu 10.279 dan kecemasan yaitu 8.909.

Peneliti selanjutnya melakukan uji multiple regression untuk mengetahui pengaruh variabel dukungan sosial dan religiusitas terhadap kecemasan. Namun sebelumnya peneliti melakukan uji asumsi. Hasil uji asumsi dan regrsi diuraikan sebagai berikut:

Peneliti melakukan uji normalitas untuk mengetahui normalitas data penelitian, apakah berdistribusi normal atau tidak. Normalitas data diasumsikan terpenuhi jika sampel yang digunakan lebih dari 100 orang (Katz, 2011). Sampel yang digunakan pada penelitian ini sebanyak 151 orang, sehingga peneliti tidak lagi melakukan uji normalitas dan data tersebut dinyatakan berdistrubusi normal.

Kemudian, peneliti melakukan uji linearitas untuk melihat adanya linearitas hubungan antara variabel dependen dan variabel independen. Hasil uji linearitas diperoleh nilai $p=0.575(p>0.05)$ pada hubungan antara dukungan sosial dengan

kecemasan. Kemudian, $p=0.219$ ( $p>$ 0.05 ) pada hubungan religiusitas dengan kecemasan. Hal tersebut menunjukkan bahwa hubungan variabel pada peneltiian ini bersifat linear.

Kemudian, peneliti melakukan uji multikoloniaritas digunakan untuk melihat keterkaitan antar variabel. Bentuk regresi yang baik adalah tidak adanya keterkaitan antar varibel. Berdasarkan uji multikoloniaritas diperoleh nilai tolerance dari dukungan sosial, religiusitas dan kecemasan sebesar 0.941 (tolerance $>0.01$ ). Nilai variance Inflation Factor (VIF) sebesar 1.063 (VIF < 10). Hal ini menunjukkan bahwa tidak terjadi multikoloniaritas antar variabel independent.

Langkah terakhir dalam uji asumsi, peneliti melakukan uji heteroskedastisitas digunakan untuk menguji apakah ada ketidaksamaan varian dari residual untuk semua pengamatan. Model regresi yang baik adalah ketika tidak terjadi heteroskedastisitas pada data. Hasil uji heteroskedastisitas menunjukkan tidak terjadi gejala heteroskedastisitas pada variabel dukungan sosial $(0.746)$ karena nilai signifikan lebih besar daripada 0.05. Namun pada variabel religiusitas (0.025) terjadi gejala heteroskedastisitas kaena nilai signifikan lebih kecil daripada 0.05 .

Kemudian peneliti melakukan uji hipotesis mengenai pengaruh dukungan sosial, religiusitas terhadap kecemasan masyarakat Indonesia dilakukan uji multiple regression. Hasil uji hipotesis diuraikan pada tabel di bawah ini: 
Tabel 6. Uji Hipotesis

\begin{tabular}{cccccc}
\hline Variabel & R & R Square & F & Signifikan & Ket. \\
\hline $\begin{array}{c}\text { Dukungan Sosial } \\
\text { Religiusitas } \\
\text { Kecemasan }\end{array}$ & 0.210 & 0.044 & 3.399 & 0.036 & Sig. \\
\hline
\end{tabular}

Pada tabel di atas diketahui nilai $R$ adalah 0.210 yang menunjukkan kekuatan hubungan antara dukungan sosial $\left(X_{1}\right)$ dan religiusitas $\left(X_{2}\right)$ dengan Kecemasan $(Y)$. Selain itu, pada tabel di atas juga diperoleh nilai $\mathrm{R}$ Square adalah 0.044 (4.4\%). Angka tersebut merupakan besarnya dukungan sosial dan religiusitas terhadap kecemasan. Kemudian, terdapat faktor-faktor lain yang tidak diteliti yang mempengaruhi kecemasan sebesar $95.6 \%$. Religiusitas memiliki pengaruh dominan daripada dukungan sosial terhadap kecemasan. Sumbangan efektif dukungan sosial $\left(X_{1}\right)$ sebesar $-0,04 \%$, sedangkan sumbangan efektif religiusitas $\left(X_{2}\right)$ sebesar $4,42 \%$ terhadap kecemasan.

Pada tabel di atas, juga diketahui nilai $\mathrm{F}$ regresi sebesar 3.399 dan nilai signifikan yang diperoleh sebesar $0.036<0.05$ yang artinya signifikan. Hal ini menunjukkan bahwa ada pengaruh dukungan sosial dan religiusitas terhadap kecemasan warga Indonesia dalam masa pandemi Covid-19.

\section{Pembahasan}

Berdasarkan hasil uji hipotesis diketahui bahwa ada pengaruh dukungan sosial dan religiusitas terhadap kecemasan masyarakat yang tinggal sendiri selama masa pendemi Covid-19. Pengaruh yang dihasilkan dalam penelitian ini rendah karena disebabkan variabel-variabel lain yang tidak diteliti. Selain itu, mungkin saja dipengaruhi oleh kondisi partisipan, alat ukur, budaya dan faktor lainnya. Pada penelitian ini juga menunjukkan bahwa religiusitas memiliki pengaruh yang dominan daripada dukungan sosial terhadap kecemasan.
Seseorang yang mendapatkan dukungan sosial dan memiliki religiusitas dapat mengontrol kecemasan dalam menghadapi situasi pandemi Covid-19. Hasil penelitian ini sesuai dengan penelitian sebelumnya yang menunjukkan bahwa dukungan sosial dan religiusitas berpengaruh dan dapat mengatasi kesehatan mental, termasuk kecemasan di masa pandemi Covid-19 (Oktavia \& Muhopilah, 2021). Demikian pula penelitian sebelumnya yang dilakukan oleh Hughes, Tomlinson, Blumenthal, Davidson, Sketch \& Watkins, 2004) menunjukkan bahwa dukungan sosial dan religiusitas berpengaruh dan dapat mengatasi kecemasan. Dukungan sosial merupakan faktor eksternal, sedangkan religiusitas merupakan faktor internal yang akan memengaruhi perasaan cemas seseorang dalam menghadapi situasi pandemi Covid-19.

Covid-19 memengaruhi kesejahteraan psikologis seseorang seperti kecemasan, depresi dan gejala stress pasca-trauma (Ahmed, Ahmed, Aibao, Hanbin, Siyu \& Ahmad, 2020; Cao, Fang, Hou, Han, Xu, Dong \& Zheng, 2020; Wang, Pan, Wan, Tan, Xu, Ho \& Ho, 2020). Kecemasan merupakan salah satu aspek psikologis yang paling banyak dialami oleh masyarakat di masa pandemi (Ifdil, Yuca \& Yendi: 2020). Kecemasan merupakan respon individu terhadap suatu hal yang mengancam atau berbahaya (Moss, 2002). Masyarakat memiliki persepi dan pikiran bahwa Covid-19 merupakan hal yang berbahaya sehingga menimbulkan ketakutan fisiologis dan beraktivitas dalam sehari-hari. Terdapat beberapafaktoryang menjadi pemicu kecemasan masyarakat di masa pandemi, di antaranya kekhawatiran terinfeksi, paparan 
berlebihan terkait berita Covid-19, keadaan kesehatan, regulasi emosi yang rendah, jarak dari daerah yang termasuk zona zona infeksius, durasi karantina yang lama dan jenis kelamin perempuan (Zhafir Asyura, ArRizq, \& Siagian, 2020; Anindyajati, Wiguna, Murtani, Christian, Wigantara, Putra, Hanafi, Minayati, Ismail, Kaligis, Savitri, Uiterwaal \& Diatri, 2021). Hal tersebut membuat masyarakat mengalami kecemasan.

Ifdil, Yuca \& Yendi (2020) menyatakan bahwa masyarakat di masa pandemi Covid-19 mengalami kecemasan dengan berbagai tingkatan, dari yang kondisi kecemasan yang rendah, kecemasan sedang dan kecemasan tinggi.

Kecemasan lebih dirasakan oleh mereka yang tinggal sendiri selama pandemi Covid-19 dari pada seseorang yang tinggal bersama dengan keluarga. Sebuah studi penelitian menemukan bahwa individu yang tinggal sendiri di masa pandemi Covid-19 mengalami tingkat kecemasan yang tinggi daripada seseorang yang tinggal dengan keluarga dan teman (Sundarasen, Chinna, Kamaludin, Nurunnabi, Baloch, Khoshaim, Hossain \& Sukayt, 2020). Seseorang yang tinggal sendiri terkadang jauh dari keluarga dan merasakan ancaman terkait keselamatan dan keamanan di masa pandemi Covid-19. Selain itu, seseorang yang tinggal sendiri merasa kesepian dan mengalami kesepian yang lebih selama pandemi Covid-19 (Bu, Steptoe \& Fancourt, 2020). Kesepian dapat dipahami sebagai akibat dari hubungan sosial dan aktivitas sosial yang tidak terpenuhi (Tesch-Romer \& Huxhold, 2019).

Orang-orang membutuhkan dukungan sosial dalam mengatasi kecemasan di masa pandemi Covid-19. Dukungan sosial adalah sumber daya sosial untuk menghadapi persitiwa kehidupan yang penuh tekanan, seperti masa pandemi Covid-19 saat ini. Cohen, Underwood \& Gottlieb (2000) menyatakan bahwa dukungan sosial merupakan bagian yang utama dalam meningkatkan kesehatan dan kesejahteraan seseorang. Yasin \& Dzulkifli (2010) dalam studi penelitian yang mereka lakukan menunjukkan bahwa seseorang memiliki masalah psikologis yang rendah ketika memiliki tingkat dukungan sosial yang tinggi.

Dukungan sosial secara efektif dapat meredakan kecemasan, depresi dan stres yang dialami di masa pandemi Covid-19 (Xiao, Zhang, Kong, Li \& Yang, 2020). Penelitian yang serupa juga dilakukan oleh Ozmete \& Pak (2020) menunjukkan bahwa dukungan sosial berdampak pada tingkat kecemasan seseorang di masa pendemi Covid-19. Tingkat kecemasan akan berkurang ketika dukungan sosial yang dirasakan meningkat (Ozmete \& Pak, 2020; Ao, Zhu, Meng, Wang, Ye, Yang, Dong \& Martek, 2020). Dukungan sosial dapat diperoleh dari berbagai sumber yaitu keluarga, teman, komunitas dan orangorang yang terkait dengan diri. Di antara sumber dukungan sosia tersebut, keluarga merupakan sumber dukungan sosial yang utama di masa pandemi Covid-19, kemudian diikuti dengan teman-teman disekitar (Alnazly, Khraisat, Al-Bashaireh \& Bryant: 2021). Penelitian sebelumnya yang dilakukan oleh Roohafza, Afshar, Keshteli, Mohammadi, Feizi, Taslimi \& Adibi (2014) menunjukkan bahwa keluarga merupakan dukungan sosial yang utama dalam mengatasi kecemasan. Teman atau anggota keluarga dapat memberikan dukungan sosial atau emosional, interaksi sosial dan dapat mengurangi emosi negatif dan meningkatkan mood (Segrin \& Passalaqua, 2010; Eray, Ucar \& Murat, 2017). Hal tersebut sesuai hasil penelitian ini diperoleh bahwa dukungan sosial yang dibutuhkan seseorang terdiri dari beberapa bentuk yaitu kasih sayang, informasi, petunjuk, finansial dan lainnya. Kasih sayang dapat dijadikan sebagai kekuatan dalam diri seseorang bahwa mereka tidak sendiri untuk menjalani kehidupan dalam masa pandemi Covid-19. Selain itu, informasi dan petunjuk 
yang diperoleh akan membantu seseorang mengatasi hal-hal negatif yang akan terjadi dan menjadi pemicu munculnya perasaan cemas. Semakin banyak dukungan sosial yang diperoleh, maka seseorang akan merasa tenang dalam menghadapi pandemi Covid-19.

Kecemasan seseorang yang dialami di masa pandemi Covid-19 juga berkaitan dengan tingkat religiusitas yang dimiliki. Religiusitas merupakan kemampuan seseorang untuk mengetahui, menghayati dan menerapkan nilai agama yang dianut dalam kehidupan (Jalaluddin, 2012). Pada penelitian ini diperoleh bahwa kecemasan yang dialami seseorang di masa pandemi Covid-19 dipengaruhi oleh tingkat religiusitas. Wahyuni, Sutarno \& Andika (2020) melakukan penelitian yang serupa dan menunjukkan hasil bahwa tingkat kecemasan yang dialami seseorang di masa pandemi Covid-19 berkaitan dengan tingkat religiusitas yang ada pada diri seseorang. Penelitian meta analisis yang berkaitan dengan religiusitas yang dilakukan oleh Stewart, dkk (2016) sebanyak 32 penelitian menunjukkan bahwa religiusitas sangat membantu dalam mengatasi kecemasan. Religiusitas dapat dijadikan sebagai koping dalam menghadapi situasi pandemi Covid-19.

Pargament (dalam Gomez-Benito, Abdel-Khalek, Nuno \& Lester, 2019) mengemukakan bahwa religiusitas sebagai koping yang efektif ketika menghadapi masalah dan kesulitan, seperti kecemasan. Thomas \& Barbato (2020) menunjukkan dalam penelitian yang telah dilakukan bahwa religiusitas sebagai koping yang membantu individu mengatasi kecemasan, depresi dan gangguan psikologis lainnya yang dialami di masa pandemi Covid-19. Religiusitas dapat diapllikasikan dengan berbagai cara dalam kehidupan sehari-hari, seperti dalam agama Islam di antaranya salat lima waktu, berwudhu, membaca Al-Quran, mengingat Allah, panggilan dan doa serta berpuasa (AbdelKhalek, Nuno, Gomez-Benito \& Lester, 2019). Seseorang yang memiliki tingkat religiusitas yang tinggi akan merasakan kebahagiaan, kesenangan dan merasa aman sehingga menimbulkan ketenangan batin dan memiliki daya tahan dalam mengatasi hal-hal yang menekan (Sapuan \& Hendarsih, 2014). Oleh karena itu, seseorang harus mengisi waktu dengan berbagai kegiatan keagamaan di masa pandemi Covid-19 saat ini. Sargolzaei, Bedhani \& Ghorbani dalam Safara \& Bhatia (2008) mengemukakan bahwa menghabiskan waktu untuk kegiatan keagamaan akan menurunkan tingkat kecemasan yang dirasakan. Individu yang percaya terhadap tuhan dan ajarannya dapat menciptakan kesehatan mental dalam kehidupan di masa pandemi Covid-19. Berbagai sikap keagamaan dapat secara langsung dan tidak langsung dalam mengatasi kecemasan (Shahabi, Yazdi, Mashhadi \& Hasani, 2017).

Namun terdapat penelitian yang berbeda dengan penelitian sebelumnya yang menunjukkan bahwa religiusitas dengan kecemasan tidak signifikan (Muthoharoh \& Andriani, 2014). Berapa faktor yang diduga memengaruhi perbedaan yaitu alat ukur, teknik pengambilan sampel, kondisi subyek dalam keadaan religiusitas tinggi dan lain-lain. Meskipun demikian, banyak penelitian yang menunjukkan bahwa religiusitas berpengaruh terhadap kecemasan seseorang. Penelitian ini memiliki keterbatasan diantaranya penyebaran kuesioner mungkin belum maksimal sehingga jumlah partisipan dalam penelitian tidak banyak dan kurang mewakili persentase masyarakat Indonesia. Selain itu, kondisi partisipan yang tidak terkontrol. Dimana pernyataan yang diberikan partisipan terkadang tidak menunjukkan keadaan yang sebenarnya.

\section{Kesimpulan}

Dukungan sosial dan religiusitas signifikan berpengaruh terhadap kecemasan 
masyarakat yang tinggal sendiri selama pandemi Covid-19. Memperoleh dukungan sosial dan memiliki religiusitas yang baik dapat mengontrol perasaan dalam menghadapi situasi. Semakin banyak dukungan sosial yang diperoleh dari orang-orang disekitar dapat mengatasi kecemasan. Begitupun dengan religiusitas, semakin baik religiusitas yang dimiliki maka dapat mencegah dan mengurangi kecemasan yang dirasakan. Penelitian berikutnya diharapkan dapat menggunakan jumlah sampel yang lebih banyak dari segi budaya, gender dan usia. Selain itu menggunakan metode mixed untuk mendapatkan data yang lebih luas, objektif, valid dan reliabel.

\section{Daftar Pustaka}

Ahmed, M. Z., Ahmed, O., Aibao, Z., Hanbin, S., Siyu, L \& Ahmad, A. (2020). Epidemic of covid-19 in China and associated psychological problems. Asian Journal Psychiatry, 51, 102092, 1-7. https://doi. org/10.1016/j.ajp.2020.102092.

Amrai, K., Zalani, H. M., Arfai, F. S., \& Sharifian, M. S. (2011). The relationship between the religious orientation and anxiety and depression of students. Procedia Social and Behavioral Sciences, 15, 613-616. https://doi.org/10.1016/j.sbspro.2011.03.150.

Alnazly, E., Khraisat, O. M., Al-Bashaireh, A. M., \& Bryant, C. L. (2021). Anxiety, depression, stress, fear and social support during covid-19 pandemic among Jordanian healthcare workers. Plos One, 16 (3), 1-22. https://doi.org/10.1371/journal. pone. 0247679 .

Ancok, D. \& Suroso, F. N. (2011). Psikologi Islam: solusi islam atas problem-problem psikologi cetakan 4. Yogyakarta: Pustaka Pelajar.

Anindyajati, G., Wiguna, T., Murtani, B. J., Christian, H., Wigantara, N. A., Putra, A. A., Hanafi, E., Minayati, K., Ismail, R. I., Kaligis, F., Savitri, A. I., Uiterwaal, C S.P.M \& Diatri, H. (2021). Anxiety and its associated factors during the initial phase of the Covid-19 pandemic in Indonesia.
Front Psychiatry, 21. 634585. https://doi. org/10.3389/fpsyt.2021.634585.

Anna, L. K. (2020). Tingkat kecemasan akibat wabah virus corona meningkat. Diterima 28 Mei 2020 dari https://lifestyle.kompas. com.

Ao, Y., Zhu, H., Meng, F., Wang, Y., Ye, G., Yang, L., Dong, N., \& Martek, I. (2020). The impact of social support on public anxiety amidst the covid-19 pandemic in China. International Journal of Environmental Research and Public Health, 17 (23), 1-14.

Azwar, S. (2015). Penyusunan skala psikologi. Yogyakarta: Pustaka Belajar.

Barrera, M. (1986). Distinctions betwewwn social support concepts, measures, and models. American Journal of Community Psycholoy, 14, 413-445. https://doi. org/10.1007/BF00922627.

Bu, F., Steptoe, A \& Fancourt, D. (2020). Who is lonely in lockdown? Cross-cohort analyses of predictors of loneliness before and during the Covid-19 pandemic. Public Health, 186, 31-34. https://doi.org/10.1016/j. puhe.2020.06.036.

Cao, W., Fang, Z., Hou, G., Han, M., Xu, X., Dong, J \& Zheng, J. (2020). The psychological impact of the covid-19 epidemic on college students in China. Psychiatry Research, 287, 112934, 1-5. https://doi.org/10.1016/j.psychres. 2020. 112934

Cohen, S., Gottlieb, B. H., \& Underwood, L. G. (2000). Social relationship and health. In S. Cohen, L. G. Underwood, \& B. H. Gottlieb (Eds.), Social support measurement and intervention: A guide for health and social scientists (p.3-25). Oxford University Press. $\quad$ https://doi.org/10.1093/med:psy ch/9780195126709.003.0001

Craske, M. G., \& Stein, M. B. (2016). Anxiety. www.thelance.com, 388, 48-59. https://doi. org/10.1016/S0140-6736(16)30381-6.

Djalante, R., Lassa, J., Setiamarga, D., Sudjatma, A., Indrawan, M., Haryanto, B., Mahfud, C., Sinapoy, M. S., Djalante, S., Rafliana, I., Gunawan, L. A., Surtiari, G. A. K., \& Warsilah, H. (2020). Review and analysis of current responses to 
covid-19 in Indonesia: period of January to march 2020. Progress in Disaster Science, 6, 1-37. https://doi.org/10.1016/j. pdisas.2020.100091.

Eray, S., Ucar, H. N., \& Murat, D. (2017). The effects of relocation and social support on long-term outcomes of adolescents following a major earthquake: a controlled study from Turkey. International Journal of Disaster Risk Reduction, 24, 46-51. https://doi.org/10.1016/j.jidrr.2017.05.026.

Fetriyah, U., Mahmudah, R., Damayanti, A., \& Firdaus, S. (2019). Religiosity, social support and anxiety in mother of children with acute lymphoblastic leukemia. Proceedings of the Third International Conference on Sustainable Innovation 2019-Health Science and Nursing (ICOSIHSN 2019). https:// www.atlantis-press.com/proceedings/ icosihsn-19/125919809.

Firmansyah, M. (2020). Ancaman psikologis dan imbas cemas akibat pandemic covid-19. Diterima 30 Mei 2020 dari https://www.alinea.id.

Gomez-Benito, J., Abdel-Khalek, A. M., Nuno, L., \& Lester, D. (2019). The relationship between religiosity and anxiety: a metaanalysis. Journal of religion and health, 58 (5), 1874-1856.

Gottlieb, B. H., \& Bergen, A. E. (2010). Social support concepts and measures. Journal of Psychosomatic Research, 69, 511-520. https://doi.org/10.1016/j. jpsychores.2009.10.001.

Halgin, R \& Whitbourne, K. S. (2010). Psikologi Abnormal. Jakarta: Salemba Humanika

Hamilton, M. (1959). The assessment of anxiety states by rating. British Journal of Medical Psychology, 32, 50-55. https://doi. org/10.1111/j.2044-8341.1959.tb00467.x.

Han, B., Yan, B., Zhang, J., Zhao, N., Sun, J., Li, C., Lei, X., Liu, H., \& Chen, J. (2014). The influence of the social support on symptoms of anxiety anddepression among patients with silicosis. The Scientific World Journal, 1-7. https://doi. org/10.1155/2014/724804.

Huang, Z., Zhao, S., Li, Z., Chen, W., Zhao, L., Deng, L., \& Song, B. (2020). The battle against coronavirus disease 2019 (Covid-19): Emergency management and infection control in a radiology departemen. Journal of The American College of Radiology, 1-24. https://doi. org/10.1016/j.jacr.2020.03.011.

Huber, S., \& Huber, O. W. (2012). The centrality of religiosity scale (CRS). Religions, 3, 710-724. https://doi.org/10.3390/rel3030710.

Hughes, J. W., Tomlinson, A., Blumenthal, J. A., Davidson, J., Sketch, M. H., \& Watkins, L. L. (2004). Social support and religiosity as coping strategies for anxiety in hospitalized cardiac patients. Annals of Behavioral Medicine, 28 (3), 179-185. https:// doi: 10.1207/s15324796abm2803_6.

Ifdil, F., Yuca, V \& Yendi, F. M. (2020). Stress and anxiety among late adulthood in Indonesia during covid-19 outbreak. Jurnal Penelitian Pendidikan Indonesia, 6(2), 31-46. https://doi.org/10.29210/02020612.

Ihsanuddin. (2020). Ini pengumuman lengkap jokowi soal 2 WNI positif corona. Diterima 4 April 2020 dari https://nasional.kompas. com.

Jalaluddin. (2012). Psikologi Agama. Jakarta: PT. Raja Grafindo Persada.

Katz, M. H. (2011). Multivariable analysis: a practical guide for clinicians and public health researchers (third edition). Cambridge: The United Kingdom at the University Press.

Koenig, H. G. (2009). Research on religion, spirituality, and mental health: A review. The Canandian Journal of Psychiatry, 54 (5), 283 -291. https://doi.org/10.1177/0 70674370905400502.

Kurniawati, D. (2012). Konsep diri, dukungan sosial dan kecemasan menghadapi keadaan sakit pada pasien fraktur. Jurnal Ners, 7 (1), 31-36.

Laili, R. (2018). Pengaruh religiusitas terhadap stres pada mahasiswa di Universitas Negeri Jakarta [skripsi, Universitas Negeri Jakarta]. http://repository. unj.ac.id/3243/1/Skripsi_Rofiqoh\%20 Laili_1125140005.pdf.

Moss, D. (2002). Psychological perspectives anxiety disorders "identification and intervention".https://www.researchgate. 
net/publication/259560188_Psychological_ perspectives_Anxiety_disorders_ Identification_and_intervention.

Muthoharoh, S., \& Andriani, F. (2014). Hubungan antara religiusitas dengan kecemasan kematian pada dewasa tengah. Jurnal psikologi kepribadian dan sosial, 3 (1), 23-29.

Oktavia, W. K. \& Muhopilah, P. (2021). Model konseptual resiliensi di masa pandemi covid-19: pengaruh religiusitas, dukungan sosial dan spiritualitas. Psikologika, 26 (1), 1-18.

Ozmete, E., \& Pak, M. (2020). The relationship between anxiety levels and perceived social support during the pandemic of covid-19 in Turkey. Social Work in Public Health, 35 (7), 603-616. https://doi.org/10.1 080/19371918.2020.1808144.

Putsantra, D. P. (2020). Update corona 16 April 2020 di dunia: kasus covid-19 tembus 2 Juta. Diterima 30 Mei 2020 dari https://tirto.id.

Ramdan, I. M. (2018). Reliability and validity test of the Indonesian version of the Hamilton anxiety rating scale (HAM-A) to measure work-related stress in nursing. Jurnal Ners, 14 (1), 33-40.

Roohafza, H. R., Afshar, H., Keshteli, A. H., Mohammadi, N., Feizi, A., Taslimi, M., \& Adibi, P. (2014). What's the role of perceived social support and coping styles in depression and anxiety? Journal of Research in Medical Science. 19 (10), $944-949$.

Roohafza, H., Afshar, H., Keshteli, A. H., \& Mohammadi, N. (2014). What's the role of perceived social support and coping styles in depression and anxiety?.(2014). Journal of Research in Medical Sciences, 19 (10), 943-949.

Roy, D., Tripahty, S., Kar, S. K., Sharma, N., Verma, S. K., \& Kaushal, V. (2020). Study of knowledge, attitude, anxiety \& perceived mental healthcare need in Indian population during Covid-19 pandemic. Asian Journal of Psychiatry, 51, 1-16. https://doi.org/10.1016/j.ajp.2020. 102083
Safara, M., \& Bhatia, M. S. (2008). Relationship of religious beliefs with anxiety and depression. Delhi Psychiatry Journal, 11 (2), 177-179.

Sapuan, I., \& Hendarsih, S. (2014). Hubungan tingkat religiusitas dengan koping ibu yang memiliki anak retardasi mental di SLB Negeri 2 Yogyakarta. [skripsi, Stikes Aisyiyah Yogyakarta]. http://digilib. unisayogya.ac.id/356/1/NASKAH $\% 20$ PUBLIKASI.pdf tanggal 20 juni 2021.

Sarason, I. G., \&Sarason, B. R. (2009). Social support: Mapping the construct. Journal of Social and Personal Relationship. 26 (1), 113-120. https://doi. org/10.1177/0265407509105526.

Sari, H. P., Yahya, A. N., \& Maharani, T. (2020). Update: Total ada 5.136 kasus covid-19 di Indonesia, bertambah 297. Diterima 1 Juni 2020 dari https://nasional.kompas.com.

Segrin, C., \& Passalacqua, S. A. (2010). Functions of loneliness, social support, health behavior, and stress in associations with poor health. Health Communication, 25 (4), 312-322. https:// doi.org/10.1080/10410231003773334.

Shahabi, M, Yazdi, S. A. A., Mashhadi, A., \& Hasani, J. (2017). The role of religious attitude in coping with psychological distress and emotion regulation difficulties of UT students. Journal of pizhuhish dar din va salamat, 3 (4).

Shim. E., Tariq, A., Choi, W., Lee, Y., \& Chowell, G. (2020). Transmission potential and severity of covid-19 in South Korea. International Journal of Infectious Diseases, 93,1-16. https://doi.org/10.1016/j. ijid.2020.03.031.

Stewart, W.C., MD., Wetselaar, M. J., BA., Nelson, L. A., BS., Stewart, J. A., \& RN. (2016). Review of the effect of religion on anxiety. International Journal of depression and anxiety, 2, 1-5. https://doi. org/10.23937/2643-4059/1710016.

Stuart, G. W., \& Sundeen, S. J. (2000). Buku saku keperawatan jiwa: edisi 5 buku kedokteran jiwa. Jakarta: RGC.

Sundarasen, S., Chinna, K., Kamaludin, K., Nurunnabi, M., Baloch, G. M., Khoshaim, H. B., Hossain, S. F. A \& Sukayt, A. 
(2020). Psychological impact of covid-19 and lockdown among university students in Malaysia: Implications and policy recommendations. International Journal of Environmental Research and Public Healt, 17 (17), 1-13, https://doi.org/10.3390/ ijerph17176206.

Tamtomo, A. B. (2020). Infografik: 6 pembatasan PSBB untuk cegah covid-19. Diterima 15 April 2020 dari https://www. kompas.com.

Tesch-Roemer, C \& Huxhold, O. (2019). Social isolation and loneliness in old age. Journal of Medicine Psychology. https://doi.org/10.1093/acrefore/ 9780190236557.013.393.

Thomas, J., \& Barbato, M. (2020). Positive religious coping and mental health among christians and muslims in response to the covid-19 pandemic. Religions, 11 (10), 2-13. https://doi.org/10.3390/rel11100498.

Thomas, P., Baldwin, C., Bissett, B., Boden, I., Gosselink, R., Granger, C. L., Hodgson, C., Jones, A. M., Kho, M. E., Moses, R., Ntoumenopoulos, G., Parry, S. M., Patman, S., \& Lee, L. V. D. (2020). Physiotherapy management for covid-19 in the acute hospital setting: clinical practice recommendations. Physiotherapy and Covid-19, 1, 1-27. https://doi.org/10.1016/j.jphys.2020.03.011.

Tosepu, R., Gunawan, J., Effendy, D. S., Ahmad, L. O. A. I., Lestari, H., Bahar, H., \& Asfian, P. (2020). Correlation between weather and covid-19 pandemic in Jakarta, Indonesia. Science of The Total Environment, 1-13. https://doi.org/10.1016/j. scitotenv.2020.138436.

Ulfadhina, N. (2015). Perbedaan tingkat kecemasan mahasiswa yang tinggal di pondokan (Kos) dan yang tinggal dengan orang tua pada mahasiswa semester VI Fakultas kedokteran di Universitas Muhammadiyah Yogyakarta tahun 2015 [karya tulis ilmiah, Universitas Mumhammadiyah Yogyakarta]. http:// repository.umy.ac.id/handle/123456789/8680 tanggal 14 April 2020.

Wahyuni, I., Sutarno., \& Andika, R. (2020). Hubungan tingkat religisuitas dengan tingkat kecemasan mahasiswa di masa pandemic Covid-19. Jurnal Kesehatan AlIrsyad, 2, 131-144.

Wang, C. Pan, R., Wan, X., Tan, Y., Xu, L., Ho, C. S \& Ho, R. C. (2020). Immediate psychological responses and associated factors during the initial stage of the 2019 coronavirus disease (covid-19) epidemic among the general population in China. International Journal of Environmental Research and Public Health, 17 (5), 1-25. https://doi.org/10.3390/ijerph17051729.

WHOa. (2020). Pertanyaam dan jawaban terkait coronavirus. Diterima 29 Mei 2020 dari https://www.who.int/indonesia/news/ novel.

WHOb. (2020). Coronavirus disease (Covid-19) Situation reports. Diterima 29 Mei 2020 dari https://www.who.int.

Wijayanti, R. (2016). Perbedaan tingkat kecemasan mahasiswa tahun pertama FK-UMM yang tinggal di Indekos dengan yang tinggal bersama orang tua. [karya tulis ilmiah, Universitas Muhammadiya Malang]. http://eprints.umm.ac.id/34704/ .

Xiao, H., Zhang, Y., Kong, D., Li, S., \& Yang, N. (2020). The effects of social support on sleep quality of medical staff treating patients with coronavirus disease 2019 (Covid-19) in January and February 2020 in China. Medical Science Monitor, 26.

Yasin, M. A. S. M \& Dzulkifli, M. A. (2010). The Relationship social support and psychological prombles among students. International journal of business and social science, 1 (3), 110-116.

Zhafir Asyura, M. M. A., Ar-Rizq, M. F. \& Siagian, R. M. (2021). Analisis perubahan psikososial: depresi dan ansietas selama pandemi Covid-19 pada kalangan pelajar. JIMKI, 8(3), 174-188. 